\title{
Polymerization of Bis-Oxetanes Consisting of Oligo-Ethylene Oxide Chain with Lithium Salts as Initiators
}

\author{
Yoshiyuki Miwa, Hiromori Tsutsumi, ${ }^{*} \dagger$ and Tsutomu OISHI* \\ Ube Laboratory, Corporate Research \& Development, Ube Ind. Ltd., 1-12-32 \\ Nishihonmachi, Ube, Yamaguchi 755-8633, Japan \\ * Department of Applied Chemistry and Chemical Engineering, Faculty of Engineering, \\ Yamaguchi University, 2-16-1 Tokiwadai, Ube, Yamaguchi 755-8611, Japan
}

(Received December 28, 2000; Accepted April 4, 2001)

\begin{abstract}
New bis-oxetanes with oligo-ethylene oxide chain, 1,9-bis(3-ethyl-3-oxetanyl)-2,5,8-trioxanonane, 1,12-bis(3-ethyl-3-oxetanyl)-2,5,8,11-tetraoxadodecane, and 1,15-bis(3-ethyl-3-oxetanyl)-2,5,8,11,14-hexaoxapentadecane were prepared from 3-ethyl-3-hydroxymethyloxetane and di-, tri-, or tetra-ethylene glycol. Cationic ring-opening polymerization of bis-oxetanes with initiators based on various lithium salts such as $\mathrm{LIBF}_{4}, \mathrm{LiPF}_{6}$, $\mathrm{LiN}\left(\mathrm{CF}_{3} \mathrm{SO}_{2}\right)_{2}$, and $\mathrm{LiN}\left(\mathrm{C}_{2} \mathrm{~F}_{5} \mathrm{SO}_{2}\right)_{2}$ was investigated by FT-IR spectroscopy. Addition of lithium salts to the bis-oxetanes induced rapid and uncontrollable polymerization. Addition of polar solvents such as acetone, acetonitrile to the mixture containing the bis-oxetanes and lithium salts forbade polymerization. Removing the polar solvent from the mixture initiated polymerization and provided poly(oxetane)-lithium salt complexes that can be applied to solid polymer electrolytes. The kind of polar solvent and lithium salt and length of the ethylene oxide chains in the bis-oxetanes influenced reaction rates of the bis-oxetanes and crystallinities of the resulting poly(oxetane)-lithium salt complexes.
\end{abstract}

KEY WORDS Ring-Opening Polymerization / Polyether / Lithium Salts / Oxetane /

Polyethylene oxide (PEO), polypropylene oxide (PPO) and the polymers partially involving these structures have been much studied for applications to polymer electrolytes because they dissolve lithium salts, efficiently, and assist ion transport in the matrixes. ${ }^{1,2}$ These polymers are synthesized by ring-opening polymerization of cyclic ethers and the degree of polymerization for polymer electrolytes is controlled by anionic initiators. ${ }^{3}$ These initiators should be removed perfectly from the polymer matrix because impurities derived from the initiators may affect ion transport in the polymer electrolyte and/or formation of passivating film on the electrodes (lithium and positive electrodes). ${ }^{4}$

We investigated the preparation and polymerization of oxetane derivatives (DDOE, TrDOE, and TeDOE) as shown in Figure 1 to acquire polyether-like matrix that is similar to PEO and PPO (see Figure 2). Polymerization of the oxetane derivatives, initiated by various catalysts including cationic initiators ${ }^{5-9}$ such as $\mathrm{BF}_{3}$,
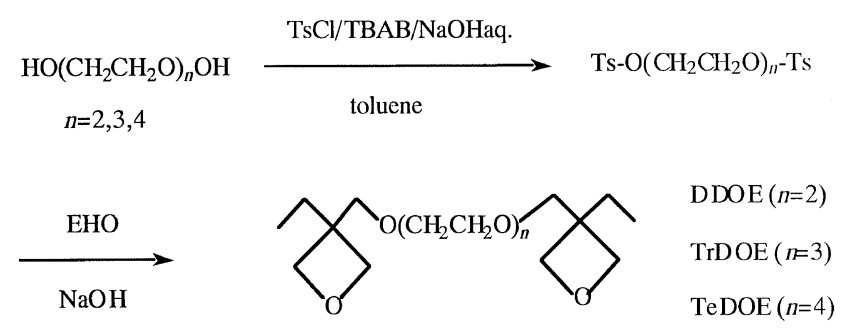

Figure 1. Synthesis of bis-oxetanes.

${ }^{\dagger}$ To whom correspondence should be addressed.
$\mathrm{AlCl}_{3}, \mathrm{SbCl}_{5}, \mathrm{PF}_{5}, \mathrm{Et}_{3} \mathrm{OPF}_{6}, \mathrm{Et}_{3} \mathrm{OBF}_{4}$, and $\left(\mathrm{C}_{4} \mathrm{H}_{9}\right)_{3} \mathrm{Al}$, was carried out lithium salts as initiators to obtain matrix polymers accessible for solid polymer electrolytes. However, direct preparation of poly(oxetane)-lithium salt complex from the mixture that consists of the oxetane monomer and a large amount of the salt, is not preferable for film formation because of rapid polymerization of the mixture. Solid polymer electrolytes must
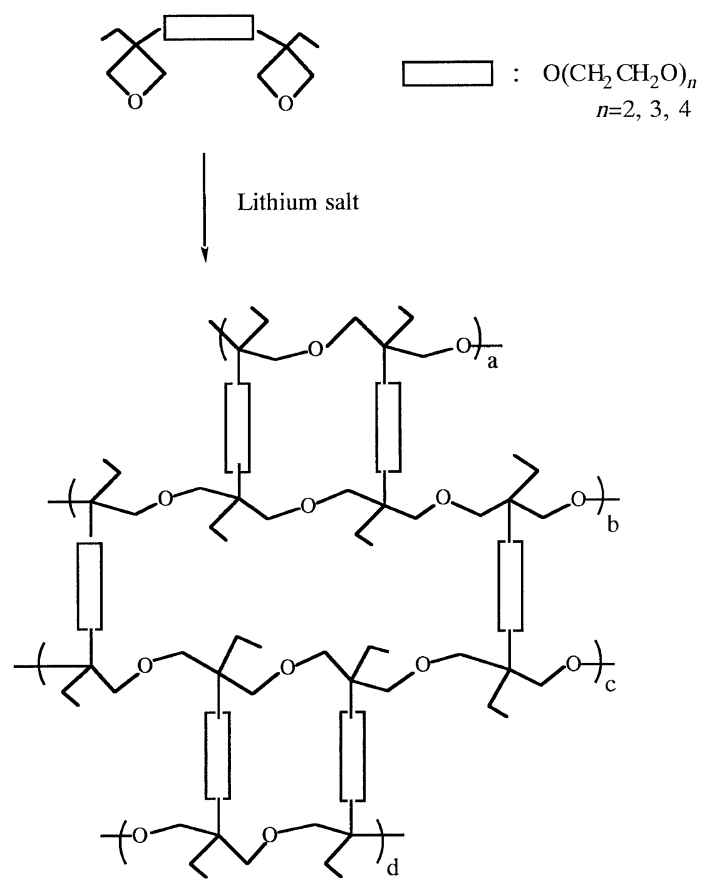

Figure 2. Schematic presentation of polymerization of bisoxetane monomer and its polymer network structure. 
include a large amount of lithium salt for production of charge carriers, anions and cations. If we control the initiation of the polymerization of the oxetane-lithium salt mixture, this simple procedure gives impurity-free polymer electrolytes directly, because no lithium salts as initiators are entirely needed to be removed from the polymers.

This paper describes the retardation of the polymerization of oxetanes in the oxetane-lithium salt mixtures, polymerization of the oxetane derivatives (DDOE, TrDOE, and TeDOE) consisting of oligo-ethylene oxide units with the lithium salts, and fundamental properties of the resulting polymer-lithium complexes.

\section{EXPERIMENTAL}

\section{Materials}

Reagent grade acetone, toluene, tetrahydrofuran, and acetonitrile were purchased from Katayama Chem., Japan, and purified by standard procedures. Diethylene glycol, triethylene glycol, and tetraethylene glycol were purchased from Tokyo Kasei, Japan, and distilled before use. Tetrabutylammonium bromide (TBAB) and $p$-toluenesulfonyl chloride ( $\mathrm{TsCl}$ ) were purchased from Aldrich Chem., USA, and Tokyo Kasei, respectively and used without further purification. $\mathrm{LiBF}_{4}$ and $\mathrm{LiPF}_{6}$ were from Katayama Chem. and used without further purification. $\mathrm{LiN}\left(\mathrm{CF}_{3} \mathrm{SO}_{2}\right)_{2}$ and $\mathrm{LiN}\left(\mathrm{C}_{2} \mathrm{~F}_{5} \mathrm{SO}_{2}\right)_{2}$ were obtained from $3 \mathrm{M}$, USA, and used after drying at $130^{\circ} \mathrm{C}$ for $13 \mathrm{~h}$ under vacuum. 3-Ethyl-3-hydroxyethyloxetane (EHO) was prepared by the method of Pattison. ${ }^{10}$

\section{Measurements}

${ }^{1} \mathrm{H}$ NMR spectroscopy was performed on a JEOL GSX-400 spectrometer using $\mathrm{CDCl}_{3}$ as solvent containing tetramethylsilane as the internal standard. Mass spectra were recorded on a Shimadzu Model GC-MS QP1000 instrument using chemical ionization techniques with ammonia. Gas chromatographic analysis was performed with a Shimadzu Model GC-14B instrument. The peak areas in the gas chromatogram were determined with a Shimadzu Chromatopac C-R5A integrator. Differential scanning calorimetry (DSC) was carried out with a Shimadzu thermal analyzer DSC-50 instrument at a heating rate of $10^{\circ} \mathrm{C} \mathrm{min}-1$ under helium. An indium standard was used to calibrate the instrument. $T_{\mathrm{g}}, T_{\mathrm{m}}$, and $\Delta H_{\mathrm{m}}$ were determined using a TA 50 software package. Viscosity data were obtained using a Tokyo Seiki viscosimeter Visconic ED at $20^{\circ} \mathrm{C}$.

\section{FT-IR Measurement}

IR spectra were recorded on a Nicolet Magna 550 spectrometer equipped with a SPECAC spectra reflectance accessory (model 19650) which had a temperature control unit. The IR chamber was purged with dry nitrogen to avoid moisture. Solutions consisting of oxetane monomers, lithium salts and acetonitrile were directly deposited onto the surface of a stainless disc heated on the hot stage with a controlled thickness between 20 and $40 \mu \mathrm{m}$. Spectra were scanned every $1 \mathrm{sec}-$ ond or 1 minute during measurement. Changes of infrared absorption bands of the oxetane monomer can be monitored as a function of time. The peak at $2880 \mathrm{~cm}^{-1}$ corresponding to the $\mathrm{C}-\mathrm{H}$ band stretching vibration was used as the internal standard for kinetic calculations. Because the intensity of the IR spectra is determined by the sample thickness, deformation of the film, such as shrinkage during the cure process may affect absorption intensity.

Conversion of polymerization reaction was directly related to decrease of absorption on the IR spectra as follows.

$$
\text { Conversion }(\%)=\frac{A_{0}-A_{\mathrm{t}}}{A_{0}} \times 100
$$

where $A_{0}$ and $A_{\mathrm{t}}$ represent the absorption at oxetane ether bands in $830 \mathrm{~cm}^{-1}$ (or $981 \mathrm{~cm}^{-1}$ ) at about $1.5 \mathrm{~min}$. after casting the sample solution onto the stainless disc and at time, $t$, respectively. The rate of polymerization for the oxetane monomer $\left(R_{\mathrm{p}}\right)$ was determined as,

$$
R_{\mathrm{p}}=\frac{\left(A_{\mathrm{t} 1}-A_{\mathrm{t} 2}\right)[M]}{\left(t_{2}-t_{1}\right) A_{0}}
$$

where $A_{0}, A_{\mathrm{t} 1}$ and $A_{\mathrm{t} 2}$ are $830 \mathrm{~cm}^{-1}$ (or $981 \mathrm{~cm}^{-1}$ ) absorptions at times to $t_{0}, t_{1}$, and $t_{2}$. $[M]$ is the initial concentration of an oxetane. Monitoring of the oxetane- $\mathrm{LiPF}_{6}$ mixture was carried out at $981 \mathrm{~cm}^{-1}$ absorption and the other oxetane- $\mathrm{LiBF}_{4}$, $\mathrm{LiN}\left(\mathrm{CF}_{3} \mathrm{SO}_{2}\right)_{2}$, and $\mathrm{LiN}\left(\mathrm{C}_{2} \mathrm{~F}_{5} \mathrm{SO}_{2}\right)_{2}$ mixture were done at $830 \mathrm{~cm}^{-1}$ absorption, because noticeable intereference from lithium salts was observed for the oxetane-lithium mixture.

\section{Synthesis of Oxetane Monomers}

1,9-Bis(3-ethyl-3-oxetanyl)-2,5,8-trioxanonane (DD$O E$ ). Thirty-five weight percent of aqueous sodium hydroxide solution (185 g) was slowly added to a solution of $p$-toluenesulfonyl chloride (197.2 g, $1.04 \mathrm{~mol}$ ) and tetrabutylammonium bromide $(16.8 \mathrm{~g}, 0.052 \mathrm{~mol})$ in toluene $(400 \mathrm{~mL})$, cool to $10^{\circ} \mathrm{C}$, and diethylene glycol $(50.0 \mathrm{~g}, 0.471 \mathrm{~mol})$ added dropwise over $1 \mathrm{~h}$. The temperature was allowed to rise to room temperature and the reaction mixture was stirred at room temperature over $4 \mathrm{~h}$. A white suspension formed gradually. 3Ethyl-3-hydroxymethyloxetane (120.0 g, $1.13 \mathrm{~mol})$ was slowly added to the reaction mixture, grains of sodium 
hydroxide (56.5 g, $2.26 \mathrm{~mol})$ were added over $1 \mathrm{~h}$, and the mixture was refluxed with stirring for an additional $4 \mathrm{~h}$ after continued heating at $60^{\circ} \mathrm{C}$ for $1 \mathrm{~h}$. After adding distilled water $(300 \mathrm{~mL})$ to dissolve sodium chloride precipitates, the mixture was extracted successively with toluene $(300 \mathrm{~mL})$. The extract was washed twice with distilled water $(200 \mathrm{~mL})$, and dried over anhydrous sodium sulfate. The solvent was removed and the remaining light yellow liquid was distilled at $1 \mathrm{mmHg}$ $\left(173-178^{\circ} \mathrm{C}\right)$ to give DDOE $(47.0 \mathrm{~g}, 33 \%$ yield to diethylene glycol, $99 \%$ pure by GC).

${ }^{1} \mathrm{H}$ NMR $\left(\mathrm{CDCl}_{3}\right) \delta\left(\mathrm{ppm}=0.8-0.9\left(\mathrm{t}, 3 \mathrm{H}, \mathrm{CH}_{3}-\right.\right.$ $\left.\mathrm{CH}_{2}-\right)$; $1.7-1.8\left(\mathrm{q}, 2 \mathrm{H}, \mathrm{CH}_{3}-\mathrm{CH}_{2}-\right)$; $3.6(\mathrm{~s}, 2 \overline{\mathrm{H}},-$ $\left.\mathrm{C} \overline{\mathrm{H}_{2}} \mathrm{O}-\right)$; $3.6-3.7\left(\mathrm{~m}, 8 \mathrm{H},-\mathrm{O}-\overline{\mathrm{CH}}_{2} \mathrm{CH}_{2}-\right) ; 4.4-4.5$ (dd, $4 \mathrm{H},-\mathrm{O}-\mathrm{CH}_{2}-$ on oxetane ring). Molecular weight. Calculated for $\overline{\mathrm{C}}_{16} \mathrm{H}_{30} \mathrm{O}_{5}$ : 302 . Found by mass spectroscopy $\left(\mathrm{M}+\mathrm{NH}_{4}^{+}\right)$: 320. Anal. Calcd for $\mathrm{C}_{16} \mathrm{H}_{30} \mathrm{O}_{5}$ : C, 63.55; H, 10.00\%. Found: C, 62.28; H, 10.41\%.

1, 12-Bis(3-ethyl-3-oxetanyl)-2, 5, 8, 11-tetraoxadodecane (TrDOE). TrDOE was prepared as above for DDOE, using triethylene glycol instead of diethylene glycol. TrDOE of the desired product was obtained at $37 \%$ yield $\left(190-195^{\circ} \mathrm{C} / 1 \mathrm{mmHg}, 98.5 \%\right.$ pure by GC) to triethylene glycol.

${ }^{1} \mathrm{H}$ NMR $\left(\mathrm{CDCl}_{3}\right) \delta(\mathrm{ppm})=0.8-0.9\left(\mathrm{t}, 3 \mathrm{H}, \mathrm{CH}_{3}\right.$ $\left.-\mathrm{CH}_{2}-\right)$; $1.7-1.8\left(\mathrm{q}, 2 \mathrm{H}, \mathrm{CH}_{3}-\mathrm{CH}_{2}-\right)$; $3.6(\mathrm{~s}, 2 \overline{\mathrm{H}}$, $\left.-\mathrm{CH}_{2} \mathrm{O}-\right)$; 3.6-3.7 (m, $\left.12 \mathrm{H},-\mathrm{O}-\overline{\mathrm{CH}_{2}} \mathrm{CH}_{2}-\right)$; 4.4-4.5

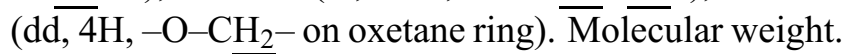
Calculated for $\overline{\mathrm{C}}_{18} \mathrm{H}_{34} \mathrm{O}_{6}$ : 347; Found by mass spectroscopy $\left(\mathrm{M}+\mathrm{NH}_{4}^{+}\right)$: 365. Anal. Calcd for $\mathrm{C}_{18} \mathrm{H}_{34} \mathrm{O}_{6}$ : C, $62.40 ; \mathrm{H}, 9.89 \%$. Found: C, 60.71; H, 10.27\%.

1, 15-Bis(3-ethyl-3-oxetanyl)-2, 5,8,11,14-hexaoxapentadecane (TeDOE). TeDOE was prepared as above for DDOE, using tetraethylene glycol instead of diethylene glycol. TeDOE of the desired product was obtained at $30 \%$ yield $\left(203-205^{\circ} \mathrm{C} / 1 \mathrm{mmHg}, 99.0 \%\right.$ pure by GC) to tetraethylene glycol. ${ }^{1} \mathrm{H} \mathrm{NMR}\left(\mathrm{CDCl}_{3}\right)$ $\delta(\mathrm{ppm})=0.8-0.9\left(\mathrm{t}, 3 \mathrm{H}, \mathrm{CH}_{3}-\mathrm{CH}_{2}-\right) ; 1.7-1.8(\mathrm{q}, 2 \mathrm{H}$, $\left.\mathrm{CH}_{3}-\mathrm{CH}_{2}-\right) ; 3.6\left(\mathrm{~s}, 2 \mathrm{H},-\overline{\mathrm{CH}}_{2} \mathrm{O}-\right) ; 3.6-3.7(\mathrm{~m}, 16 \mathrm{H}$, $\left.-\mathrm{O}-\mathrm{CH}_{2} \mathrm{CH}_{2}-\right) ; 4.4-4.5\left(\mathrm{dd}, \overline{4 \mathrm{H}},-\mathrm{O}-\mathrm{CH}_{2}-\right.$ on oxetane ring). Molecular weight. Calculated for $\mathrm{C}_{20} \mathrm{H}_{38} \mathrm{O}_{7}$ : 390; Found by mass spectroscopy $\left(\mathrm{M}+\mathrm{NH}_{4}^{+}\right): 408$. Anal. Calcd for $\mathrm{C}_{20} \mathrm{H}_{38} \mathrm{O}_{7}$ : C, 61.51; H, 9.81\%. Found: C, 60.12; H, 10.11\%.

\section{Polymerization of the Oxetane Monomers}

A typical procedure for the polymerization of the oxetane monomer is as follows. DDOE $(0.3 \mathrm{~g}, 1.0 \mathrm{mmol})$ was added to $\mathrm{LiBF}_{4}(0.070 \mathrm{~g}, 0.75 \mathrm{mmol})$ in acetonitrile $(0.76 \mathrm{~mL})$. The oxetane solution was poured into an aluminum foil dish and heated at $70^{\circ} \mathrm{C}$ for $2 \mathrm{~h}$ under a dry nitrogen atmosphere.

\section{RESULTS AND DISCUSSION}

Retardation of the Polymerization of Oxetane Derivatives with Oligo-Ethylene Oxide Units in the OxetaneLithium Salts Mixtures by Polar Solvent Addition

We selected four lithium salts, $\mathrm{LiBF}_{4}, \mathrm{LiPF}_{6}$, $\mathrm{LiN}\left(\mathrm{CF}_{3} \mathrm{SO}_{2}\right)_{2}$, and $\mathrm{LiN}\left(\mathrm{C}_{2} \mathrm{~F}_{5} \mathrm{SO}_{2}\right)_{2}$ to polymerize the oxetanes, DDOE, TrDOE, and TeDOE, which can be polymerized by the usual cationic catalysts, considering that the resulting polymers will be applied to solid polymer electrolytes. ${ }^{11}$ The oxetanes presumably polymerize with these lithium salts by the same mechanism by which their polymerization is initiated by a coordination of Lewis acids or cationic species $\left(\mathrm{H}^{+}\right)$to an oxygen atom in an oxetane ring. ${ }^{5}$

It is difficult to suppress rapid ring-opening polymerization of the oxetanes with $\mathrm{LiBF}_{4}$ and $\mathrm{LiPF}_{6}$, because the lithium salts which are as active as general cationic catalysts to oxetanes, are introduced into the oxetane in much larger quantities $(\sim 30 \mathrm{wt} \%)$ than the usual amounts of catalysts $(c a . \quad 0.5 \mathrm{wt} \%)^{12}$ in order to use the polymer-lithium salt complexes as polymer electrolytes. Figure 3 shows variation in viscosity of the mixture that consists of DDOE, a lithium salt, and a polar solvent. Gelation of the DDOE-LiBF 4 mixture gave a polymer in a relatively short time. No viscositytime curve of DDOE-LiPF 6 mixture could be measured owing to its rapid polymerization.

Addition of acetone or acetonitrile to these mixtures extended gelation time remarkably. No increase of the viscosity of DDOE-LiBF 4 and DDOE-LiPF 6 solution containing acetonitrile occurred over one day or more

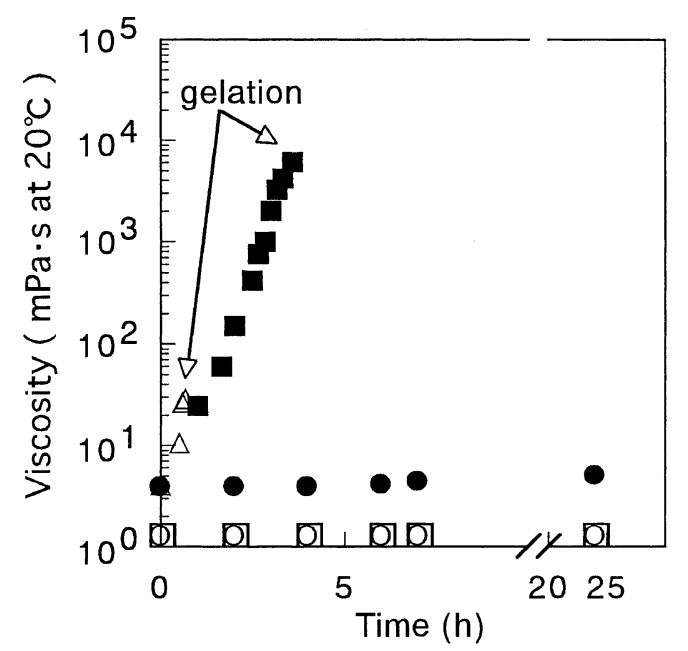

Figure 3. Variation in viscosity of DDOE-lithium salts mixture with time. Solvent type-wt $\%$, lithium salt type, mol ratio of lithium salt/oxetane: $(\square)$ bulk, $\mathrm{LiBF}_{4}, 0.103$; $(\triangle) \mathrm{THF}-39, \mathrm{LiBF}_{4}, 3.23$; (O) acetone-33, $\mathrm{LiBF}_{4}, 3.23 ;(\bigcirc)$ acetonitrile-30, $\mathrm{LiBF}_{4}, 3.23$; ( $\square$ ) acetonitrile-37, $\mathrm{LiPF}_{6}, 3.23$. 
at $20^{\circ} \mathrm{C}$. This indicates that the polymerization of the oxetanes with lithium salts is depressed by addition of acetone or acetonitrile. Acetone showed such retarded effect on the DDOE-LiBF 4 mixture, not on the DDOE-LiPF $_{6}$ mixture. The retarded effect of acetone was not so great that the viscosity of the solution increased gradually, but very slowly as shown in Figure 3. The catalytic activity of $\mathrm{LiPF}_{6}$ to the oxetane is thus stronger than that of $\mathrm{LiBF}_{4}$, and acetonitrile more effectively prevents initiation of polymerization of the oxetane by lithium salts than acetone does. The retardation of polymerization by acetone and acetonitrile was observed in TrDOE- or TeDOE-lithium salts mixture.

All polar solvents that have large solvation energy to dissolve lithium salts cannot prevent the rapid polymerization of the oxetane-lithium salt mixture. They do not promote polymerization of the oxetane smoothly without hindrance when evaporated from solution. THF is generally a good solvent to dissolve lithium salts, but not for control of rapid poymerization of the oxetane$\mathrm{LiBF}_{4}$ mixture, as shown in Figure 3. Polar solvents such as methyl acetate, ethyl acetate, methyl isobutylketone, and propylene carbonate, behaved like THF toward the mixture. Other polar solvents such as DMSO and DMF prevented the rapid polymerization of the oxetane-lithium salt mixture for a long time as acetonitrile did, but did not promote smooth polymerization of the oxetane when evaporated from solution by heating.

Figure 4 shows FT-IR spectra in the presence of polar solvents in the oxetane-lithium salt mixtures. The spectra of acetone and acetonitrile are also shown in Figures $4 \mathrm{a}$ and $4 \mathrm{c}$. Characteristic absorption bands of acetonitrile are shown at $2253 \mathrm{~cm}^{-1}$ and $2293 \mathrm{~cm}^{-1}$ in $-\mathrm{CN}$ stretching vibration (Figure $4 \mathrm{c}$ ), and those of ace-

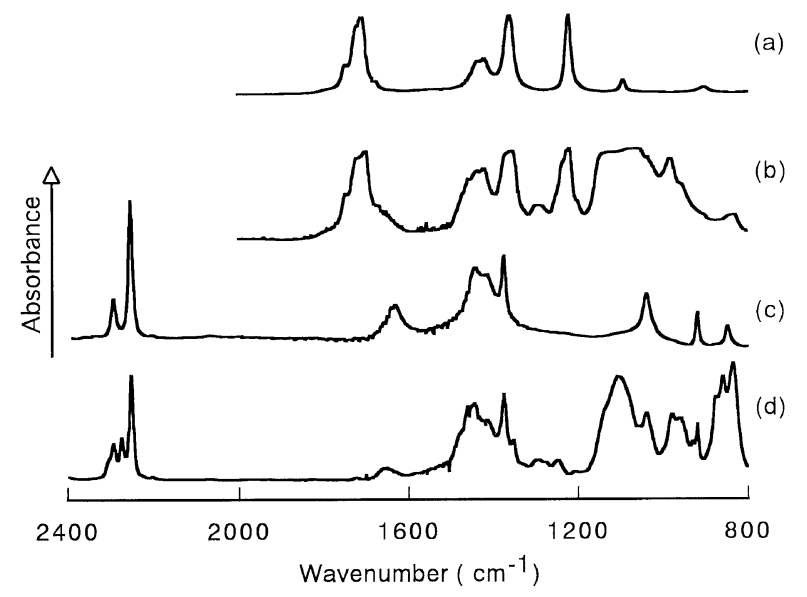

Figure 4. FT-IR spectra of DDOE oxetane monomer with lithium salts. (a) Acetone; (b) $\mathrm{DDOE} / \mathrm{LiBF}_{4}$ (1/0.802 mol ratio, $38 \mathrm{wt} \%$ in acetone); (c) acetonitrile; (d) DDOE/LiPF 6 (1/0.879, $42 \mathrm{wt} \%$ in acetonitrile). tone are shown at $1215 \mathrm{~cm}^{-1}$ in $\mathrm{C}-\mathrm{C}-\mathrm{C}$ stretching and deformation vibration and $1710 \mathrm{~cm}^{-1}$ in $-\mathrm{C}=\mathrm{O}$ stretching vibration. A new peak at $2273 \mathrm{~cm}^{-1}$ was observed in the acetonitrile solution containing DDOE and $\mathrm{LiPF}_{6}$ as shown in Figure $4 \mathrm{~d}$. In acetone solution, shoulders appeared at 1215 and $1710 \mathrm{~cm}^{-1}$. The shift and broadening of the absorption bands results from coordination of lithium ions to $-\mathrm{CN}^{13}$ and $-\mathrm{C}=\mathrm{O},{ }^{14,15}$ respectively. The results suggest that lithium ions in the solution are more interactive with solvent molecules than oxetane molecules. Therefore, the initiation of the polymerization of the oxetanes is forbidden or prolonged.

\section{Polymerization of Oxetane Derivatives by Lithium Salt}

Reactions of oxetanes were monitored by FT-IR during and after evaporation of acetonitrile from the acetonitrile solution containing the oxetane and lithium salt directly deposited on the surface of a stainless disc. Figures 5 and 6 show the IR spectra of the polymerization process of DDOE caused by $\mathrm{LiPF}_{6}$ and $\mathrm{LiBF}_{4}$ at $28^{\circ} \mathrm{C}$. At the start of measurement, the absorption band $\left(919 \mathrm{~cm}^{-1}\right)$ based on acetonitrile was detected in both systems, and readily disappeared with the passage of time. The disappearance of the absorption bands based on acetonitrile and oxetane occurred simultaneously. The absorption bands of the oxetane in the $\mathrm{LiPF}_{6}$ system disappeared immediately as soon as that of acetonitrile began to disappear, whereas in the $\mathrm{LiBF}_{4}$ system the disappearance of absorption bands of the oxetane occurred slowly after that of acetonitrile perfectly vanished.

Figure 7 shows conversion-time curves of DDOElithium salt systems at different temperatures. At

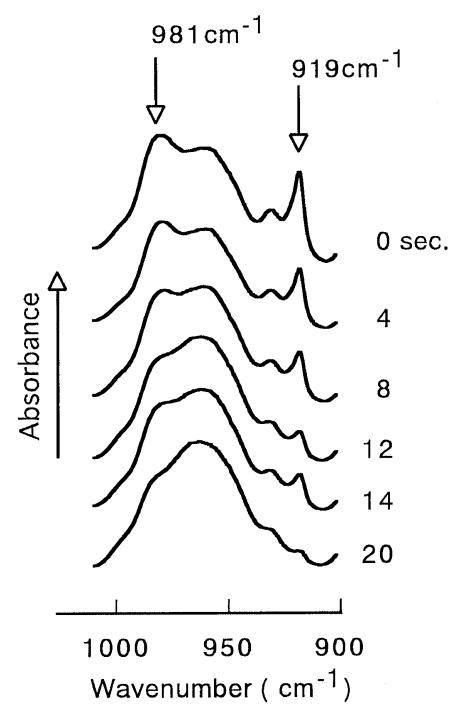

Figure 5. FT-IR spectra for reaction of DDOE oxetane monomer at $28^{\circ} \mathrm{C}$, with evaporation of acetonitrile contained in the DDOE-LiPF $_{6}$ system. DDOE $/ \mathrm{LiPF}_{6}$ mol ratio $=1 / 0.75,40 \mathrm{wt} \%$ in acetonitrile. 


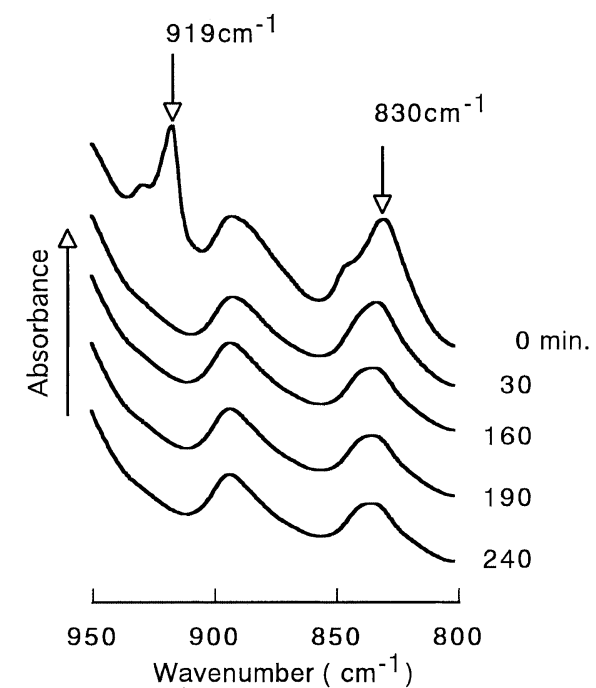

Figure 6. FT-IR spectra for the reaction of DDOE at $28^{\circ} \mathrm{C}$, with evaporation of acetonitrile contained in the $\mathrm{DDOE}_{-} \mathrm{LiBF}_{4}$ system. $\mathrm{DDOE} / \mathrm{LiBF}_{4}$ mol ratio $=1 / 0.75,38 \mathrm{wt} \%$ in acetonitrile at $28^{\circ} \mathrm{C}$.

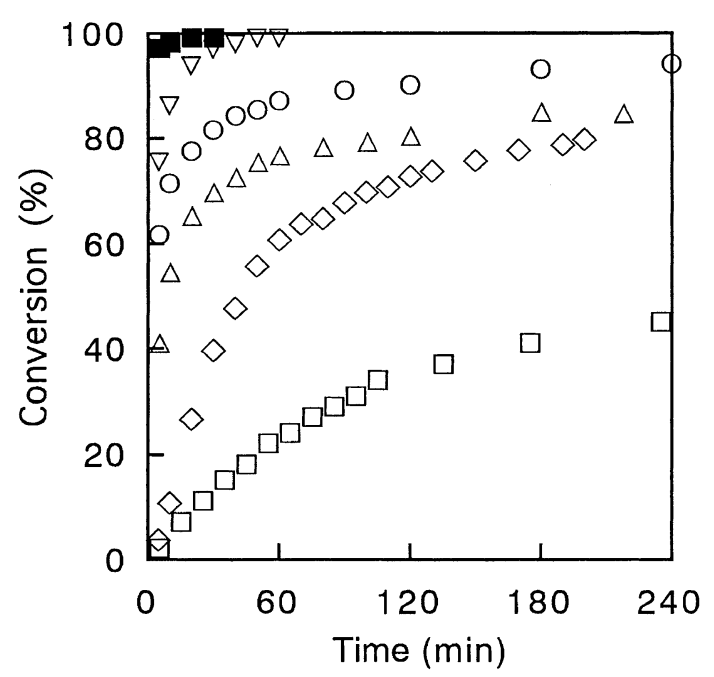

Figure 7. Conversion-time curves of DDOE (DDOE/lithium salt mol ratio $=1 / 0.75,40 \mathrm{wt} \%$ in acetonitrile) with different lithium salts and temperatures. $\mathrm{DDOE} / \mathrm{LiPF}_{6}:(\mathbf{\square}) 28^{\circ} \mathrm{C} ; \mathrm{DDOE} / \mathrm{LiBF}_{4}$ : $(\square) 28^{\circ} \mathrm{C} ;(\diamond) 40^{\circ} \mathrm{C} ;(\triangle) 50^{\circ} \mathrm{C} ;(\bigcirc) 60^{\circ} \mathrm{C} ;(\nabla) 70^{\circ} \mathrm{C}$.

the start of polymerization, the conversion increases rapidly above $40^{\circ} \mathrm{C}$. The progressively slowing down observed at each temperature is the result of network formation and consecutive gelation that reduces the segmental mobility of growing polymer chains and of unreacted oxetane monomers.

Reactivity between oxetane monomers (TrDOE and TeDOE) and lithium salt was controlled by the addition of the acetonitrile. The rates of polymerization of DDOE, TrDOE, and TeDOE at $50^{\circ} \mathrm{C}$ in the oxetane- $\mathrm{LiBF}_{4}$ system, which have the same mol ratio of oxetane/LiBF 4 (1/0.75), are shown in Figure 8. The conversion curve of the TrDOE-LiBF 4 system is similar to that of the DDOE system, indicating rapid increase followed by progressive slowing down of the rate of

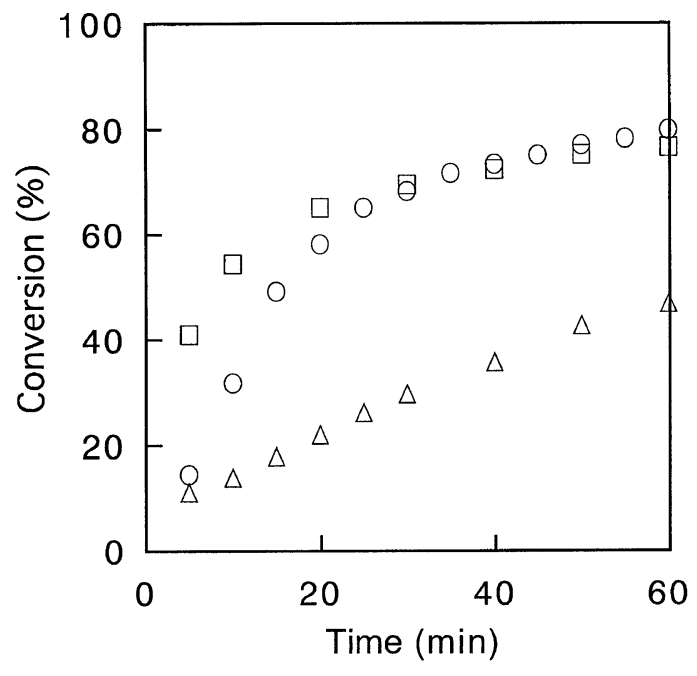

Figure 8. Conversion-time curves of various oxetane monomers (oxetane monomer/lithium salt mol ratio $=1 / 0.75,38 \mathrm{wt} \%$ in acetonitrile ) with $\mathrm{LiBF}_{4}$ at $50^{\circ} \mathrm{C}$. $(\square) \mathrm{DDOE} ;(\bigcirc) \operatorname{TrDOE} ;(\triangle)$ TeDOE.

polymerization. The conversion curve of the TeDOE$\mathrm{LiBF}_{4}$ system did not show rapid increase in the rate of polymerization.

$R_{\mathrm{p}} /[M]^{\max }$ estimated from the conversion-time curves of DDOE, TrDOE, and TeDOE at different temperatures are summarized in Table I (see experimental section). It is likely that the reactivity of these oxetanes is influenced by the length of ethylene oxide (EO). The longer length of EO chain in the oxetanes is the lower rate of their reactions. Comparing $R_{\mathrm{p}} /[M]^{\max }$ of DDOE, TrDOE, and TeDOE, the reactivity order was DDOE $>\operatorname{TrDOE}>\mathrm{TeDOE}$ at $50^{\circ} \mathrm{C}$, and DDOE $\fallingdotseq$ TrDOE $>$ TeDOE at $70^{\circ} \mathrm{C}$. The order of reactivity of DDOE at $28^{\circ} \mathrm{C}$ was the same as that of TeDOE at $50^{\circ} \mathrm{C}$. The conversion of the oxetanes was over $80 \%$ at $2 \mathrm{~h}$ except that of DDOE at $28^{\circ} \mathrm{C}$ and TeDOE at $50^{\circ} \mathrm{C}$ (Table I). $R_{\mathrm{p}} /[M]^{\max }$ at $50^{\circ} \mathrm{C}$ reveal remarkable differences: 8.2 (DDOE), 3.3 (TrDOE), 0.7 (TeDOE). The oxetane derivatives having the longer length of EO chain can capture more lithium ions since EO has strong interaction $^{16-18}$ with metal ions. Consequently, the reaction rates decrease owing to decrease of lithium ions that participate in the initiation of oxetane. ${ }^{19}$

We investigated other lithium salts, $\mathrm{LiN}\left(\mathrm{CF}_{3} \mathrm{SO}_{2}\right)_{2}$ and $\mathrm{LiN}\left(\mathrm{C}_{2} \mathrm{~F}_{5} \mathrm{SO}_{2}\right)_{2}$ for polymerization of the oxetanes. Figure 9 shows conversion-time curves of DDOE using $\mathrm{LiN}\left(\mathrm{CF}_{3} \mathrm{SO}_{2}\right)_{2}$ and $\operatorname{LiN}\left(\mathrm{C}_{2} \mathrm{~F}_{5} \mathrm{SO}_{2}\right)_{2}$ as initiator and $R_{\mathrm{p}} /[M]^{\max }$ acquired from these results are summarized in Table I. The ability of $\operatorname{LiN}\left(\mathrm{CF}_{3} \mathrm{SO}_{2}\right)_{2}$ and $\mathrm{LiN}\left(\mathrm{C}_{2} \mathrm{~F}_{5} \mathrm{SO}_{2}\right)_{2}$ to initiate the polymerization of oxetanes was much lower than that of $\mathrm{LiBF}_{4}$ and $\mathrm{LiPF}_{6}$. The polymerization of the oxetanes did not entirely proceed at $80^{\circ} \mathrm{C}$, and did so slowly over $100^{\circ} \mathrm{C}$. The conversion of the oxetanes went up to $90 \%$ for $2 \mathrm{~h}$ at $120^{\circ} \mathrm{C}$, 
Table I. Comparison of the reactivity of oxetane monomers ${ }^{\mathrm{a}}$ and properties of the resulting polymers

\begin{tabular}{|c|c|c|c|c|c|c|c|}
\hline \multicolumn{6}{|c|}{ Polymerization } & \multicolumn{2}{|c|}{$\mathrm{DSC}^{\mathrm{b}}$} \\
\hline Monomer & Initiator & $\frac{\text { Temperature }}{{ }^{\circ} \mathrm{C}}$ & $\frac{R_{\mathrm{p}} /[M]^{\max ^{C}}}{\min ^{-1}}$ & $\frac{\text { Conv }}{\% / 2 \mathrm{~h}}$ & $\frac{\text { sion }}{0 / 5 \mathrm{~h}}$ & $\frac{T_{\mathrm{g}}}{{ }^{\circ} \mathrm{C}}$ & $\frac{T_{\mathrm{m}}}{{ }^{\circ} \mathrm{C}}$ \\
\hline DDOE & $\mathrm{LiBF}_{4}$ & 28 & 0.5 & 37 & & & \\
\hline " & " & 40 & 1.2 & 80 & & & \\
\hline " & " & 50 & 8.2 & 80 & & & \\
\hline " & " & 60 & 12.4 & 90 & & -19.3 & 150.9 \\
\hline " & " & 70 & 15.1 & $100^{\mathrm{b}}$ & & -30.1 & 153.2 \\
\hline TrDOE & $"$ & 50 & 3.3 & 85 & & & \\
\hline " & " & 60 & 7.0 & 92 & & -32.5 & 115.2 \\
\hline " & " & 70 & 16.7 & 92 & & -43.0 & 115.8 \\
\hline TeDOE & " & 50 & 0.7 & 61 & & & \\
\hline " & " & 60 & 5.3 & 90 & & -27.6 & 100.2 \\
\hline " & " & 70 & 10.6 & 91 & & -40.0 & 105.6 \\
\hline DDOE & $\mathrm{LiPE}_{6}$ & 28 & $>19.6$ & $100^{\mathrm{e}}$ & & & \\
\hline " & $\mathrm{LiN}\left(\mathrm{CF}_{3} \mathrm{SO}_{2}\right)_{2}$ & 100 & 1.1 & 87 & 91 & $-2.4^{f}$ & $78.3^{f}$ \\
\hline " & " & 120 & 2.5 & 93 & 98 & $-20.6^{\mathrm{f}}$ & $81.7^{\mathrm{f}}$ \\
\hline " & $\mathrm{LiN}\left(\mathrm{C}_{2} \mathrm{~F}_{5} \mathrm{SO}_{2}\right)_{2}$ & 100 & 0.7 & 78 & 91 & $-9.5^{\mathrm{f}}$ & $75.3^{\mathrm{f}}$ \\
\hline " & " & 120 & 2.4 & 87 & 98 & $-17.9^{f}$ & $73.4^{\mathrm{f}}$ \\
\hline
\end{tabular}

${ }^{a}$ Initial condition: Monomer/Initiator mol ratio $=1 / 0.75,8 \mathrm{wt} \%$ in acetonitrile with $\mathrm{LiBF}_{4}$ and $\mathrm{LiPF}_{6}$;

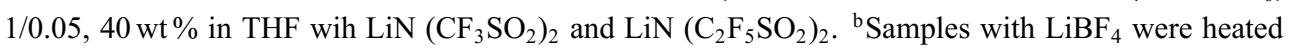
for $4 \mathrm{~h}$. ${ }^{\mathrm{C}}$ Maximum rate of polymerization. ${ }^{\mathrm{d}}$ Measured at $60 \mathrm{~min}$. ${ }^{\mathrm{e}}$ Measured at $30 \mathrm{~min}$. ${ }^{\mathrm{f}}$ Samples heated for $3 \mathrm{~h}$.

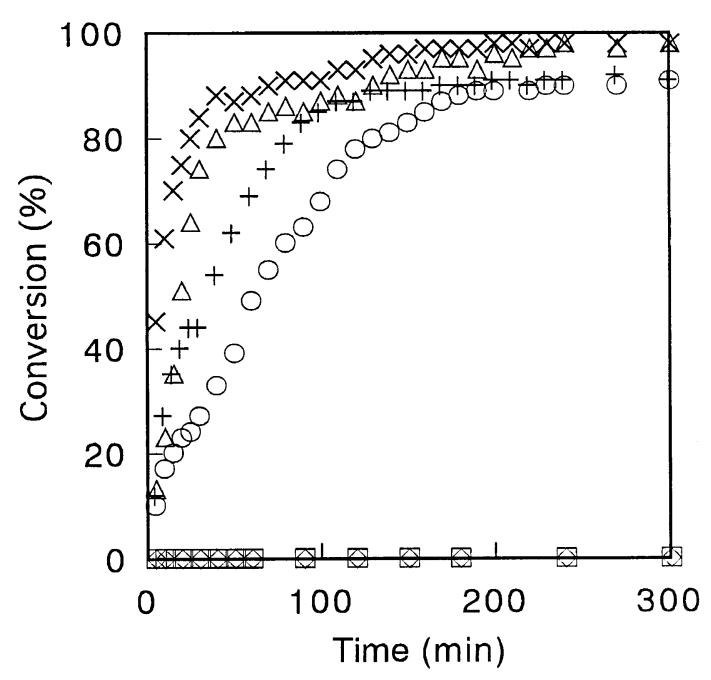

Figure 9. Conversion-time curves of DDOE (DDOE/lithium salt mol ratio $=1 / 0.05,40 \mathrm{wt} \%$ in THF) with different lithium salts and temperatures. $\mathrm{LiN}\left(\mathrm{CF}_{3} \mathrm{SO}_{2}\right)_{2}:(\square) 80^{\circ} \mathrm{C} ;(\bigcirc) 100^{\circ} \mathrm{C} ;(\triangle)$ $120^{\circ} \mathrm{C} . \mathrm{LiN}\left(\mathrm{C}_{2} \mathrm{~F}_{5} \mathrm{SO}_{2}\right)_{2}:(\diamond) 80^{\circ} \mathrm{C} ;(+) 100^{\circ} \mathrm{C} ;(\times) 120^{\circ} \mathrm{C}$.

and almost $100 \%$ for an additional time of $3 \mathrm{~h}$.

\section{Characterization of Poly(oxetane)-Lithium Salt Com- plexes}

DSC is particularly important in studying the morphology of the polymer-lithium salt complex. Thermal analysis results for polyDDOE, polyTrDOE, and polyTeDOE prepared with $\mathrm{LiBF}_{4}$ at $60^{\circ} \mathrm{C}$ and $70^{\circ} \mathrm{C}$ are listed in Table I, and DSC thermograms of the complexes polymerized at $70^{\circ} \mathrm{C}$ are shown in Figure 10. Compared with $T_{\mathrm{g}}$ of polyDDOE, polyTrDOE,

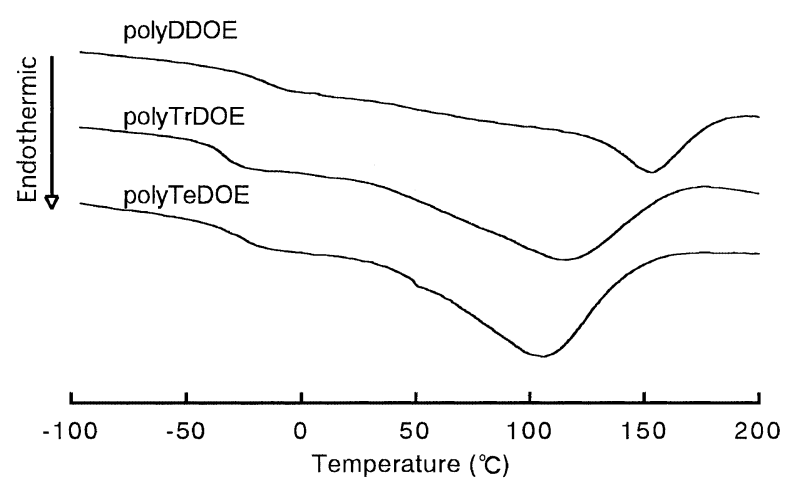

Figure 10. DSC thermograms of poly(oxetane)- $\mathrm{LiBF}_{4}$ complex prepared at $70^{\circ} \mathrm{C}$ for $4 \mathrm{~h}$. Oxetane $/ \mathrm{LiBF}_{4}=1 / 0.75 \mathrm{~mol}$ ratio.

and polyTeDOE prepared at $60^{\circ} \mathrm{C}$ and $70^{\circ} \mathrm{C}$, respectively, the complexes obtained at slow polymerization at $60^{\circ} \mathrm{C}$, have higher $T_{\mathrm{g}}$, indicating higher cross-linking ${ }^{20}$ associated with the formation of the network structures of poly(oxetanes), as shown in Figure 2. $T_{\mathrm{g}}$ of thermosetting polymers depend on network structures and slow rates of polymerization result in larger microgels, which result in networks having higher $T_{\mathrm{g}} .{ }^{21,22}$ Complexes obtained at $70^{\circ} \mathrm{C}$ have low $T_{\mathrm{g}}$, indicating that microgels in the complexes are smaller than those in the complexes obtained at $60^{\circ} \mathrm{C} . T_{\mathrm{g}}$ of polyDDOE was higher than those of polyTrDOE and polyTeDOE prepared at $60^{\circ} \mathrm{C}$ and $70^{\circ} \mathrm{C}$, respectively. This suggests that the decrease in flexibility of the polyDDOE is caused by the shorter length of EO units on the polymer backbone. No differences of the length of EO units in polyTrDOE and polyTeDOE influence $T_{\mathrm{g}}$. 
$T_{\mathrm{m}}$ of polyDDOE was $150.9-153.2^{\circ} \mathrm{C}$; those of poly $\operatorname{TrDOE}$ and polyTeDOE were $115.2-115.8^{\circ} \mathrm{C}$ and $100.2-105.6^{\circ} \mathrm{C}$, respectively. Increase in the length of EO units in the oxetane monomers decreased $T_{\mathrm{m}}$ of their polymer-lithium salt complexes. Intermolecular cross-linking is known to be caused by interactions of lithium ions with polar EO units to give rise to crystalline complexes with considerably higher melting points. $^{23-25}$ This formation of crystalline complexes in polyDDOE, polyTrDOE, and polyTeDOE presumably produces high $T_{\mathrm{m}}$. Endothermic curves appear from the region of room temperature, followed by broad peaks, showing that the crystalline complexes are formed with crystallinities of high- to low-order structure. $\Delta H_{\mathrm{m}}$ in polyDDOE, polyTrDOE, and polyTeDOE prepared at $70^{\circ} \mathrm{C}$ are $97.1,147.2$, and $171.5 \mathrm{~J} \mathrm{~g}^{-1}$, respectively, showing crystallinity to increase with length of the EO chain.

The results of the thermal analysis of polyDDOE with $\mathrm{LiN}\left(\mathrm{CF}_{3} \mathrm{SO}_{2}\right)_{2}$ and $\mathrm{LiN}\left(\mathrm{C}_{2} \mathrm{~F}_{5} \mathrm{SO}_{2}\right)_{2}$ prepared at 100 or $120^{\circ} \mathrm{C}$ are summarized in Table I. $T_{\mathrm{g}}$ of the polyDDOE-LiX $\left(\mathrm{X}=\mathrm{N}\left(\mathrm{CF}_{3} \mathrm{SO}_{2}\right)_{2}\right.$ or $\left.\mathrm{N}\left(\mathrm{C}_{2} \mathrm{~F}_{5} \mathrm{SO}_{2}\right)_{2}\right)$ complexes were -2.4 and $-9.5^{\circ} \mathrm{C}$ (prepared at $100^{\circ} \mathrm{C}$ ) and -20.6 and $-17.9^{\circ} \mathrm{C}$ (prepared at $120^{\circ} \mathrm{C}$ ). $T_{\mathrm{g}}$ of the complexes prepared at $100^{\circ} \mathrm{C}$ is higher than that at $120^{\circ} \mathrm{C}$. This suggests that complexes prepared at lower temperature have higher cross-linking matrixes as described above. $T_{\mathrm{m}} \mathrm{s}$ of the polyDDOE complexes were from 73 to $82^{\circ} \mathrm{C}$ and endothermic peaks were very small. $\Delta H_{\mathrm{m}}$ of the complexes were 16.5 and $15.2 \mathrm{~J} \mathrm{~g}^{-1}$ (prepared with $\left.\mathrm{LiN}\left(\mathrm{CF}_{3} \mathrm{SO}_{2}\right)_{2}\right)$ and 19.9 and $23.2 \mathrm{~J} \mathrm{~g}^{-1}$ (prepared with $\mathrm{LiN}\left(\mathrm{C}_{2} \mathrm{~F}_{5} \mathrm{SO}_{2}\right)_{2}$ ). These values are smaller than those of complexes prepared with $\mathrm{LiBF}_{4}$. PolyDDOE-LiX $\left(\mathrm{X}=\mathrm{N}\left(\mathrm{CF}_{3} \mathrm{SO}_{2}\right)_{2}\right.$ or $\left.\mathrm{N}\left(\mathrm{C}_{2} \mathrm{~F}_{5} \mathrm{SO}_{2}\right)_{2}\right)$ complexes thus have more amorphous matrixes.

\section{CONCLUSIONS}

Oxetane derivatives containing different lengths of EO units were synthesized and were polymerized by addition of lithium salts such as $\mathrm{LiBF}_{4}, \mathrm{LiPF}_{6}$, $\mathrm{LiN}\left(\mathrm{CF}_{3} \mathrm{SO}_{2}\right)_{2}$ and $\mathrm{LiN}\left(\mathrm{C}_{2} \mathrm{~F}_{5} \mathrm{SO}_{2}\right)_{2}$ to form polymer matrixes based on ether bonds. The catalytic activity of $\mathrm{LiBF}_{4}$ and $\mathrm{LiPF}_{6}$ was strong and that of the others, weak. The former catalytic activity could be controlled by polar solvents in the oxetane-salts system. The lengths of EO chains in the oxetane derivatives affected the rates of polymerization of the oxetanes, which were slow in the oxetanes having longer chains than shorter ones. Polymerization temperature and the length of EO chains affected the structure of poly(oxetanes)-lithium salt complexes. The complexes obtained at higher tem- perature showed lower $T_{\mathrm{g}}$. The complexes obtained with the oxetane derivatives that had longer chains of EO showed lower $T_{\mathrm{g}}$ and $T_{\mathrm{m}}$. The use of lithium salts as initiators of the oxetane derivatives is a new technique for polymerization and the resulting polymer-lithium salt complexes can be applied to promising "impurityfree" solid polymer electrolytes.

\section{REFERENCES}

1. E. Kelly, J. R. Owen, and B. C. H. Steele, J. Power Sources, 14, 13 (1985).

2. A. Nishimoto, K. Agehara, N. Furuya, T. Watanabe, and M. Watanabe, Macromolecule, 32, 1541 (1999).

3. F. Alloin and J. Y. Sanchez, Electrochim. Acta, 40, 2269 (1995).

4. G. B. Appetecchi, F. Croce, F. Ronci, B. Scrosati, F. Alessandrini, M. Carewska, and P. P. Prosini, Ionics, 5, 59 (1999).

5. A. C. Farthing and R. J. Reynolds, J. Polym. Sci., 12, 503 (1954).

6. T. Saegusa, Y. Hashiomoto, and S. Matsumoto, Macromolecules, 4, 1 (1971).

7. M. Bucquoye and E. J. Goethals, Macromol. Chem., 179, 1681 (1978).

8. J. Kops and H. Spanggaard, Macromolecules, 15, 1225 (1982).

9. St. Penczek and P. Kubisa, Makromol. Chem., 130, 186 (1969).

10. D. B. Pattison, J. Am. Chem. Soc., 79, 3455 (1957).

11. Y. Miwa, H. Tsutsumi, and T. Oishi, manuscript in preparation.

12. I. Penczek and S. Penczek, Makromol. Chem., 94, 228 (1966).

13. U. S. Park, Y. J. Hong, and S. M. Oh, Electrochim. Acta, 41, 849 (1996).

14. H. L. Yeager, J. D. Fredyk, and R. J. Parker, J. Phys. Chem., 77, 2407 (1973).

15. D. Battisti, G. A. Nazri, B. Klassen, and R. Aroca, J. Phys. Chem., 97, 5826 (1993).

16. A. A. Blumberg, S. S. Pollack, and C. A. J. Hoeve, J. Polym. Sci., A2, 2499 (1964).

17. M. Yokoyama, H. Ishihara, R. Iwamoto, and H. Tadokoro, Macromolecules, 2, 184 (1969).

18. M. Watanabe, S. Nagano, K. Sanui, and N. Ogata, Polym. J., 18, 809 (1986).

19. H. Imai, T. Saegusa, S. Matsumoto, T. Tadasa, and J. Furukawa, Makromol. Chem., 102, 222 (1967).

20. M. Shinbo, N. Nishitani, and T. Takahama, J. Appl. Polym. Sci., 29, 1709 (1984).

21. R. E. Cuthrell, J. Appl. Polm. Sci., 11, 949 (1967).

22. S. C. Miska, J. A. Manson, and L. H. Sperling, "Epoxy Resins Chemistry" in ACS Symposium, Series, R. S. Bauer Ed., American Chemical Society, Washington, D. C., 1979, p 157.

23. D. E. Fenton, J. M. Parker, and P. V. Wright, Polymer, 14, 589 (1973).

24. P. V. Wright, J. Polym. Sci., Polym. Phys. Ed., 14, 955 (1976).

25. P. V. Wright, Br. Polym. J., 7, 319 (1975). 